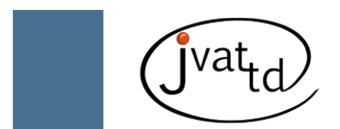

\title{
Destruction of the collection of reptiles and arthropods at Butantan Institute: a view from the United Kingdom
}

Warrell DA (1), Theakston RDG (2), Wüster W (3)

(1) Nuffield Department of Clinical Medicine, University of Oxford, John Radcliffe Hospital, Oxford, UK; (2) Alistair Reid Venom Research Unit, WHO Collaborating Centre for the Control of Antivenoms, Liverpool School of Tropical Medicine, Pembroke Place, Liverpool, UK; (3) School of Biological Sciences, University of Wales, Bangor, Wales, UK.

\section{PAIN, SYMPATHY AND ANGUISH}

Zoologists and toxinologists throughout the world are still reeling from the appalling news of the devastating fire in Butantan, which broke out on 15 May. Accumulated over a century, a collection of some 85,000 snakes and 450,000 spiders and scorpions, including many type specimens and unique examples of now-extinct species had been lost in a preservative-fuelled inferno, together with the records, notes and literature of the researchers. Amongst many other functions, this collection had proved enormously valuable in the study of animals that are the source of scientifically fascinating venoms and, indirectly, in the production of curative antivenoms. The catastrophe has not only generated enormous sympathy and sense of loss but also great anguish. These sentiments are strongly reflected, albeit in different proportions and with different degrees of optimism for the future, in the letters from two distinguished Brazilian scientists, Professors Oswaldo Sant'Anna and Maria Elena de Lima published in the last number of JVATiTD $(1,2)$. A number of important issues come to mind. How could such a tragedy have happened? What can be salvaged of the studies and careers of the affected staff? How can the vitality of this internationally renowned facility be restored?

\section{RECRIMINATIONS}

In the aftermath of the tragedy, certain senior Brazilian figures made comments that were both unsympathetic and unedifying. Their responses signified institutional jealousy and a naïve or even malicious disregard for the importance of the zoological tradition in Butantan, prompted perhaps by guilt. While blame cannot yet be specifically targeted, it is clear that responsibility for one of the world's most significant collections of venomous animals had been neglected and betrayed by those in high authority. Housing the precious jewel was a vulnerable and poorly maintained building that had become a fire trap.

The internal politics of Butantan are impenetrable mysteries to foreigners, even those whose love of the place drives them to seek understanding. We would certainly not presume to diagnose the underlying causes of this venerable institution's current malaise, but Butantan is no stranger to controversy, allegation, denunciation and violent rhetoric. Two historical examples are enshrined in the tendentious books by Afrânio do Amaral, Serpentes em Crise: à Luz de uma Legítima Defesa no "Caso do Butantan" (3), and by Eduardo Vaz, Hidra de Lerna: Lenda e Realidade (4). However, while there is a time and a purpose for forensic analysis, a more enlightened and uplifting approach is restoration and renewal. But should Butantan's collections be replaced? 


\section{THE IMPORTANCE OF NATURAL HISTORY REFERENCE COLLECTIONS}

To some, including many who should know better, natural history collections may appear to be an antiquated concept that must surely be replaced by newer and better molecular tools. In reality, nothing could be further from the truth: voucher specimens deposited in collections provide the conceptual bridge between any new data, be they molecular, toxinological, physiological or pharmacological, and the living animal in its natural environment. They remain an indispensible tool for recognizing and describing biodiversity, including that of medically important venomous animals.

\section{WHAT HAS BEEN LOST?}

The arachnological and herpetological collections of Butantan Institute, so tragically lost on 15 May 2010, represented the most comprehensive and famous collections of arachnids and snakes in the Neotropics. Together with a group of dedicated taxon specialists, they represented an unparalleled resource for research into the biodiversity of these medically and toxinologically important organisms. To those who, like the present authors, have had the immense privilege of conducting research in the collection, the loss is heartbreaking. To those Butantan researchers who have built their entire lives around the collection, the pain is beyond words. However, the fire that consumed these collections destroyed more than a research tool and many years of work by the scientists based in those departments. It also destroyed our last window on a lost world, on the environments and ecosystems existing throughout Brazil in the earlier parts of the 20th century, such as the "Araucaria" moist forests of southern Brazil and much of the Mata Atlântica, both now more than $90 \%$ replaced by man-made agricultural landscapes. Collections accumulated over many decades allow us to trace the changes in fauna and flora occurring as a result of human activity, and allow us to analyze and understand what has been destroyed. That opportunity for research is now lost forever.

The fire also consumed an important part of Brazil's scientific heritage and history: the collections incorporated the specimens collected over the course of more than a century by some of Brazil's most eminent and bestknown zoologists and biologists, like Afrânio do Amaral, Alphonse Hoge, Wolfgang Bücherl and of course Vital Brazil himself. Never again will anyone be able to experience the sense of awe that comes from seeing the jars containing original specimens collected by these pioneers on the shelves of the collection, and indeed of being able to derive genuinely useful scientific data from this material many decades after it was collected - another grievous loss to science.

\section{A CONTINUING ROLE FOR BUTANTAN'S ZOOLOGICAL COLLECTIONS}

However, the present of today will be the past of tomorrow: habitat alterations continue to alter the landscapes and ecosystems of South America at a rapid rate. If we wish to understand and describe the effects of coming change, renewed collecting activity is essential. Continuing habitat depredations, such as the Amazonian river dams planned under the Growth Acceleration Program, may provide opportunities for new collections, thus providing a baseline for assessing the effects of change on the ecosystems of the Amazon and elsewhere. Rebuilding collection-based research at Butantan is an essential part of this task: while Vital Brazil's specimens are wasted for eternity, together with the silent witnesses of long-disappeared habitats in Brazil, there are many other components of Brazil's rich biodiversity and natural heritage that remain to be documented, described and understood before they too disappear. Natural history collections will play a key role in contributing to our understanding. No institute is better placed to continue to play a pivotal role than Butantan: its rich history and talented researchers place it at the forefront of Brazilian biodiversity research, and its contribution to the documentation of South American biodiversity can and must enter a new era, with a new focus on describing the present to inform the future. The rebuilding of the biological collections at Butantan must be given the highest priority and full support by all responsible parties. 


\section{"VITALIS BRAZILIS" INITIATIVE OF THE BRAZILIAN SOCIETY OF TOXINOLOGY (SOCIEDADE BRASILEIRA DE TOXINOLOGIA - SBTX)}

In her encouraging and optimistic letter, Professor de Lima proposes the establishment of a group aimed at relaunching and replacing the collection (http://www.sbtx.org.br/noticia. php?id=25). Provision of an appropriate building seems to be relatively easy, but the problem is to restock, update and restructure the collection both with specimens and with related data. The SBTx, one of the world's most active and energetic national toxinological societies, is an appropriate agency to galvanise this plan, particularly if the overarching international organization, the International Society on Toxinology, is involved to broaden the scope of the appeal. Contacts with pharmaceutical companies and other sympathetic industrial connections both in Brazil and worldwide may also be productive.

\section{CONCLUSION}

Butantan's collection was a precious and unique resource from which mankind has benefited, including the authors of this letter. The conflagration was reminiscent of the destruction of the great library of ancient Alexandria two millennia ago, similarly depriving later generations of irreplaceable intellectual resources. It was heart breaking to see the news video clips of blackened shelves, shattered glass and our dear friends fighting to save their living arthropods. However, in the spirit of its founder and his heritage, the collection must rise again. Replacing the irreplaceable will be a very challenging and demanding project, but it may in time ensure that Butantan, that green and pleasant "oasis" in the midst of São Paulo, can resume its full role in zoology and conservation.

\section{COPYRIGHT \\ (C) CEVAP 2010}

\section{SUBMISSION STATUS}

Received: September 16, 2010.

Accepted: September 16, 2010.

Full paper published online: November 30, 2010.

\section{CONFLICTS OF INTEREST}

There is no conflict.

\section{CORRESPONDENCE TO}

DAVID A. WARRELL, Nuffield Department of Clinical Medicine, University of Oxford, John Radcliffe Hospital, Headington, Oxford OX3 9DU, UK. Phone: 441865 766865. Fax: 441865 760683. Email: david.warrell@ndm.ox.ac.uk.

\section{REFERENCES}

1. Sant'Anna OA. The fire consumed... a treasure! J Venom Anim Toxins incl Trop Dis. 2010;16(3)3989.

2. De Lima ME. "Vitalis Brazilis", burning embers, beyond the ashes, at the Butantan Institute. J Venom Anim Toxins incl Trop Dis. 2010;16(3)400-1.

3. Amaral A. Serpentes em crise: à luz de uma legítima defesa no "Caso do Butantan". São Paulo; 1941.

4. Vaz E. Hidra de Lerna: lenda e realidade. $1^{\text {st }}$ ed. São Paulo: Saraiva; 1954. 